\title{
Reconnaissance of Field Sites for the Study of Chemical Weathering on the Guayana Shield, South America
}

\author{
C. I. Steefel, B. E. Viani, A. Ramirez, K. Lee
}

February 1, 2003

U.S. Department of Energy

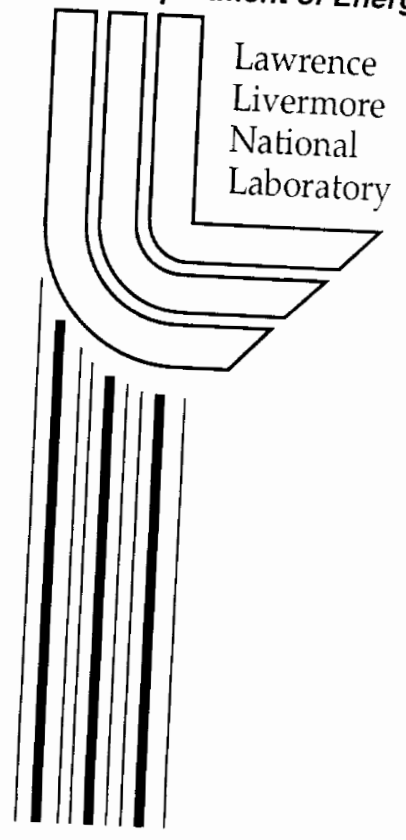




\section{DISCLAIMER}

This document was prepared as an account of work sponsored by an agency of the United States Government. Neither the United States Government nor the University of California nor any of their employees, makes any warranty, express or implied, or assumes any legal liability or responsibility for the accuracy, completeness, or usefulness of any information, apparatus, product, or process disclosed, or represents that its use would not infringe privately owned rights. Reference herein to any specific commercial product, process, or service by trade name, trademark, manufacturer, or otherwise, does not necessarily constitute or imply its endorsement, recommendation, or favoring by the United States Government or the University of California. The views and opinions of authors expressed herein do not necessarily state or reflect those of the United States Government or the University of California, and shall not be used for advertising or product endorsement purposes.

This work was performed under the auspices of the U. S. Department of Energy by the University of California, Lawrence Livermore National Laboratory under Contract No. W-7405-Eng-48.

This report has been reproduced directly from the best available copy.

Available electronically at http://www.doc.gov/bridge

Available for a processing fee to U.S. Department of Energy

And its contractors in paper from

U.S. Department of Energy

Office of Scientific and Technical Information

P.O. Box 62

Oak Ridge, TN 37831-0062

Telephone: (865) 576-8401

Facsimile: (865) 576-5728

E-mail: reports@adonis.osti.gov

Available for the sale to the public from

U.S. Department of Commerce

National Technical Information Service

5285 Port Royal Road

Springfield, VA 22161

Telephone: (800) 553-6847

Facsimile: (703) 605-6900

E-mail: orders@ntis.fedworld.gov

Online ordering: http://www.ntis.gov/ordering.htm

OR

Lawrence Livermore National Laboratory

Technical Information Department's Digital Library

http://www.llnl.gov/tid/Library.html 


\section{INTRODUCTION}

Despite the fact that chemical weathering of silicate rocks plays an important role in the draw-down of $\mathrm{CO}_{2}$ over geologic time scales (Berner and Berner, 1996), the overall controls on the rate of chemical weathering are still not completely understood. Lacking a mechanistic understanding of these controls, it remains difficult to evaluate a hypothesis such as that presented by Raymo and Ruddiman (1992), who suggested that enhanced weathering and $\mathrm{CO}_{2}$ draw-down resulting from the uplift of the Himalayas contributed to global cooling during the Cenozoic. At an even more fundamental level, the three to four order of magnitude discrepancy between laboratory and field weathering rates is still unresolved (White et al., 1996). There is as yet no comprehensive, mechanistic model for silicate chemical weathering that considers the coupled effects of precipitation, vadose zone flow, and chemical reactions. The absence of robust process models for silicate weathering and the failure to resolve some of these important questions may in fact be related-the controls on the overall rates of weathering cannot be understood without considering the weathering environment as one in which multiple, time-dependent chemical and physical processes are coupled (Malmstrom, 2000). Once chemical weathering is understood at a mechanistic process level, the important controls on chemical weathering (physical erosion, temperature, precipitation) can be folded into larger scale models tracking the global carbon cycle.

Chemical weathering of silicate rocks occurs when minerals such as Na-feldspar (albite) react with $\mathrm{CO}_{2}$ (a weak acid) or organic acid proxies in pore water, leading to the formation of various secondary phases such as the clay kaolinite. From our point of view, the reaction is of interest because it consumes $\mathrm{CO}_{2}(\mathrm{aq})$ (which freely exchanges with $\mathrm{CO}_{2}$ in the gas phase) while producing $\mathrm{HCO}_{3}{ }^{-}$(bicarbonate):

$$
\underset{\text { Albite }}{2 \mathrm{NaAlSi}_{3} \mathrm{O}_{8}}+11 \mathrm{H}_{2} \mathrm{O}+2 \mathrm{CO}_{2}=\underset{\text { Kaolinite }}{\mathrm{Al}_{2} \mathrm{Si}_{2} \mathrm{O}_{5}(\mathrm{OH})_{4}+2 \mathrm{HCO}_{3}^{-}+2 \mathrm{Na}^{+}+4 \mathrm{H}_{4} \mathrm{SiO}_{4}}
$$

The key question is what controls the rate at which this and similar reactions occur in the natural weathering environment. If the rate is largely transport-controlled, then a strong dependence of the rate on rainfall (and thus climate) and the rate of erosion is expected. If the field rates are largely reaction-controlled, then variations in rainfall and erosion rate are expected to have a relatively weak effect, although climate could have a strong effect because of the temperature dependence of the reaction rates.

The weathering of silicate rocks results in permanent reduction of $\mathrm{CO}_{2}$ (in contrast to the weathering of carbonate rocks), although the time scales over which it operates are long. While not an effect therefore that can be easily manipulated to reduce short term $\mathrm{CO}_{2}$ buildup in the atmosphere, it is essential to understand the controls on this important $\mathrm{CO}_{2}$ sink because of its prominent role in the carbon cycle over geologic periods of time. 


\section{RESEARCH GOALS}

Our goal in this study was to carry out the preliminary work needed to establish a field research site for chemical weathering om the Guayana Shield in South America. The Guayana Shield is a Precambrian province greater than 1.5 billion years old covering portions of Venezuela, Guyana (the country), Surinam, French Guiana, and Brazil (Figure 1). More important than the age of the rocks themselves, however, is the age of the erosion surface developed on the Shield, with estimates ranging as old as 65 million years. Preserved mostly in highlands, this very old erosion surface represents an endmember site where physical erosion has been significantly slower than the rate of chemical weathering. Much of the Shield is also noteworthy for the fact that chemical weathering is still occurring today, thus offering the chance to study a system in which a present day weathering regime is accompanied by an integrated weathering record over millions of years (Soler and Lasaga, 2000). If rates of chemical weathering can be determined for this very old weathering system where physical erosion is minor, they can then be compared with rates determined from sites with similar annual temperatures and rainfall, but much higher physical erosion rates. Comparative studies of this kind can provide a parameterization of chemical weathering rates as a function of physical erosion and tectonic uplift that can be used in global models for the carbon cycle.

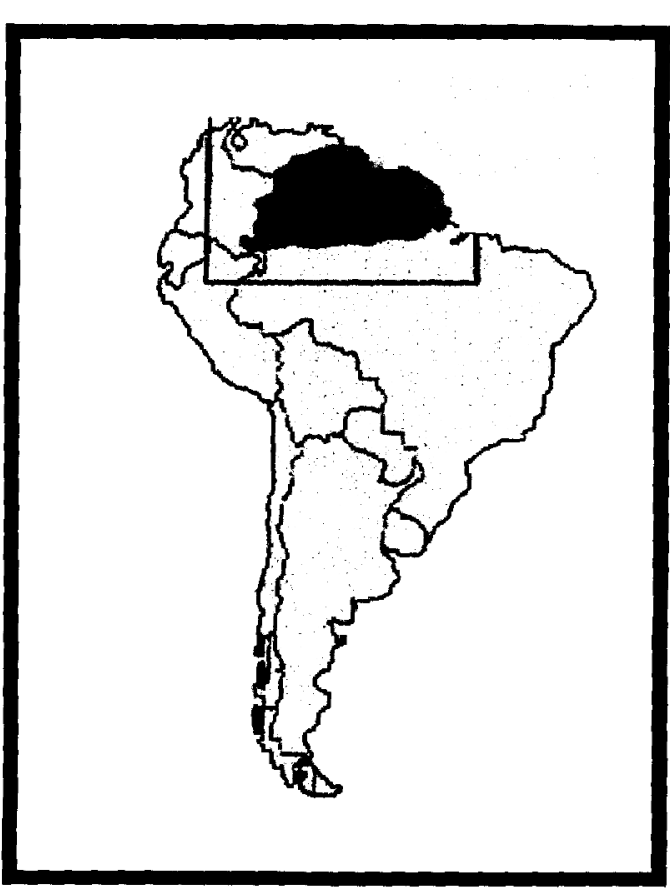

Figure 1: Location of the Precambrian Guayana Shield.
The original work plan for this six month project was to initiate field work on the Guayana Shield in Venezuela at the Los Pijiguaos bauxite mine, in collaboration with colleagues at the Universidad Central de Venezuela. The field site has the advantage of being well exposed by mining operations and located on a topographic high where the dissolved solute load from chemical weathering is not obscured by contributions from rock types other than granite. Due to safety considerations related to political unrest in Venezuela and terrorist raids across the Colombian border in the vicinity of the Los Pijiguaos mine, however, it was not possible to visit the Venezuelan site during the six month period of funding. Our colleagues from Venczuela, however, provided samples for ${ }^{10} \mathrm{Be}$ (beryllium) analysis, a cosmogenic isotope used for the quantification of physical erosion rates, and for $U$ (uranium) series disequilibria measurements, an isotopic technique used to quantify the rate of movement of the

weathering front. The Pijiguaos site is described further below. 
In lieu of doing field work in politically unstable Venezuela, the research team decided to examine deep weathering profiles ("laterites") on the Guayana Shield in Guyana, immediately to the east of Venezuela, to see if they might be suitable as field research sites to study silicate chemical weathering. Results of the field investigations are described further below.

\section{CHEMICAL WEATHERING AT LOS PIJIGUAOS, VENEZUELA}

Although weathering sites in the United States are somewhat more accessible than the Los Pijiguaos laterite deposit in Venezuela (Figure 2A), to our knowledge, none of them includes an extremely long-lived integrated record of weathering at a site where active weathering is also occurring today. The Los Pijiguaos laterite represents an end-member weathering environment in which the rate of chemical weathering matches or exceeds that of erosion. The laterite deposit is associated with an erosion surface which appears to have been initiated in the late Cretaceous-early Tertiary times (about 65 M.A.). The deposit is developed on the Precambrian Paraguaza granite, part of the Guayana Shield, and is exposed at the top of a dissected plateau at elevations between 600 and $700 \mathrm{~m}$ (Figure 2B). Because the laterite deposit is exposed only on the highest plateau, streams draining the plateau do not sample other rock types. Water and sediment samples from the streams, therefore, can be traced back unequivocally to the laterite, providing a spatially-integrated record of catchment-scale weathering.
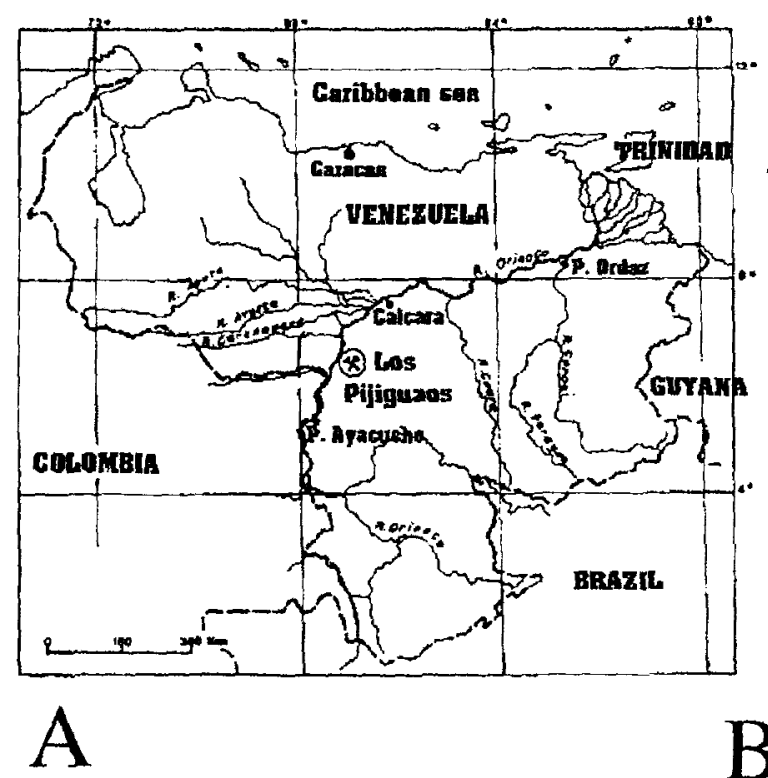

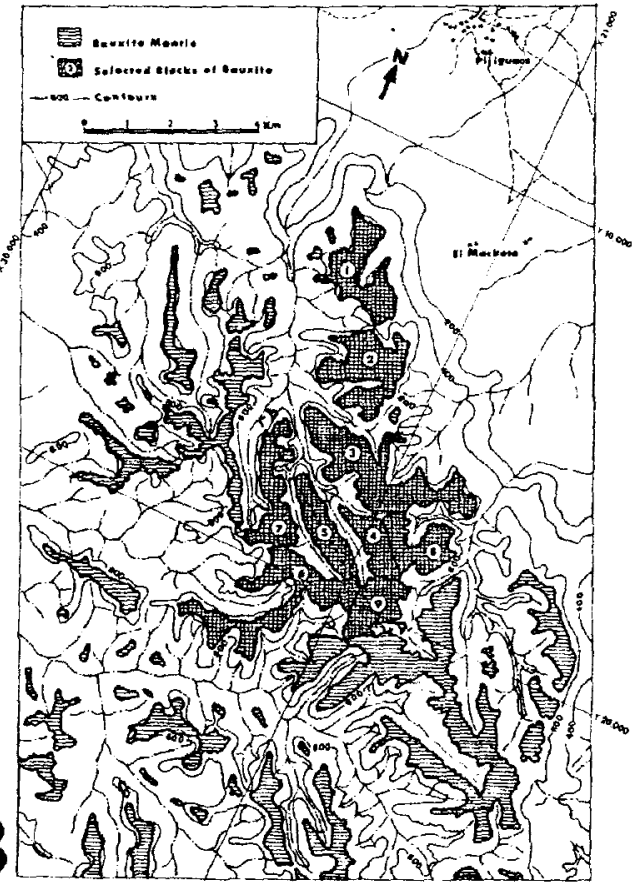

Figure 2: A) Location of the Los Pijiguaos laterite deposit. B) Geologic map of the deposit

The deposit consists of an upper portion of bauxite (dominated by the ore mineral gibbsite $\left(\mathrm{Al}(\mathrm{OH})_{3}\right)$, a mixed zone of kaolinite and gibbsite at intermediate depths, and a 


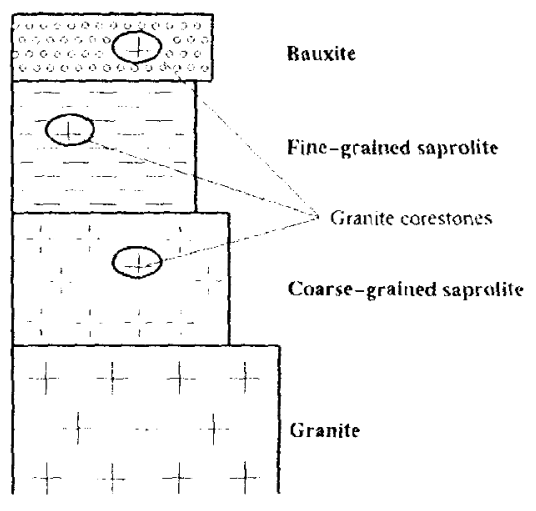

Figure 3: Simplified vertical section from the Los Pijiguaos laterite. coarse grained saprolite dominated by kaolinite directly overlying fresh granite (Figure 3). The gibbsite-rich zone, or "bauxite", represents the extreme of chemical weathering where substantial amounts of the silica, along with various alkalis like sodium, calcium, and potassium, are all leached out of the rock. Left in the weathering profile are the relatively insoluble minerals containing aluminum (gibbsite) and iron (generally goethite $[\mathrm{FeOOH}])$. Most weathering profiles show a single chemical reaction front where the primary minerals in the rock are consumed at the expense of the secondary, as in Equation 1. At Los Pijiguaos, however, the weathering has proceeded so far that a second front has developed, with gibbsite progressing downward into the profile at the expense of kaolinite according to the reaction:

$$
\underset{\text { Kaolinite }}{\mathrm{Al}_{2} \mathrm{Si}_{2} \mathrm{O}_{5}(\mathrm{OH})_{4}}+5 \mathrm{H}_{2} \mathrm{O}=\underset{\text { Gibbsite }}{2 \mathrm{Al}(\mathrm{OH})_{3}}+2 \mathrm{H}_{4} \mathrm{SiO}_{4}
$$

Preliminary measurements involving the use of $U$ series isotopes by Professor Don DePaolo and students at University of California Berkeley suggest that natural U-series disequilibrium can be used to study the reaction kinetics of sediments in-situ by evaluating the $U$ isotopic signatures of the porewaters, minerals, and surface coatings. The grain size distribution of the sediments controls the fraction of Th-234 that is released into the porefluid from the decay of U-238 in the mineral grains (Kigoshi, 1971). By knowing the fraction of U-238 decays that result in the release of Th-234 to the porewater, the dissolution rate of the host mineral (kaolinite, in this case) can be calculated if the fluid velocity is known. Samples of kaolinite-rich weathered rock were collected by collaborators at the Universidad Central de Venezuela and these will be used to carry out $U$-series isotopic measurements to quantify the rate of progression of the kaolinite dissolution front. These measurements will be carried out in the laboratory by Dr. DePaolo and students. Dissolution rates for kaolinite can be compared with those calculated using process-level reactive transport models based on experimentallydetermined rates and the discrepancies, if they exist, provide insight into the key controls on the chemical weathering rates. Reactive transport models have proven useful in interpreting weathering profiles at other sites (e.g., Steefel et al., 2002).

Another important parameter in interpreting the rates of chemical weathering based on the integrated weathering profile is the rate of physical erosion. Although we know that the physical erosion rate is very low on the erosion surface occupied by the Los Pijiguaos laterite, the rate has not yet been quantified. ${ }^{10} \mathrm{Be}$ exposure age dating can be used to 
quantify the rate of physical erosion, although the technique has not been applied to weathering profiles as old as those found on the Guayana Shield. Samples of weathered rock containing quartz were collected by Universidad Central de Venezuela collaborators. Quartz was separated from these rocks and cleaned thoroughly at Lawrence Livermore National Laboratory and the ${ }^{10}$ Be analyses are pending at the time of this report.

\section{RECONNAISSANCE OF POTENTIAL FIELD SITES IN GUYANA}

Since it was impossible to visit Venezuela during the narrow six month window of LDRD funding without risking the lives of the research team, it was decided to carry out a preliminary reconnaissance of laterites described from similar granitic rocks in Guyana, immediately to the east of Venezuela. The country of Guyana has historically been a major producer of bauxite, with laterite thicknesses almost as great as those found at Los Pijiguaos in Venezuela. Before carrying out the field reconnaissance, however, it was difficult to ascertain whether the laterite sites in Guyana would be suitable. It was not clear, for example, whether the Guyanese sites were located at high enough elevation that present day weathering was occurring. Also unclear was the extent of vegetation cover that would make delineation and sampling of the weathering profiles difficult.

A five day reconnaissance trip was made in early September of 2002 by LLNL investigators C. Steefel, B. Viani, and K. Lee. Viani is an expert in soil formation processes and clay mineralogy, while $\mathrm{K}$. Lee is an expert in unsaturated flow and transport and also had direct experience working in the Guyanese bauxite mines as a mining engineer. The LLNL investigators were joined by Dr. A. Ramirez of the Universidad Central de Venezuela, who is the leading expert on laterites developed on the Guayana Shield.

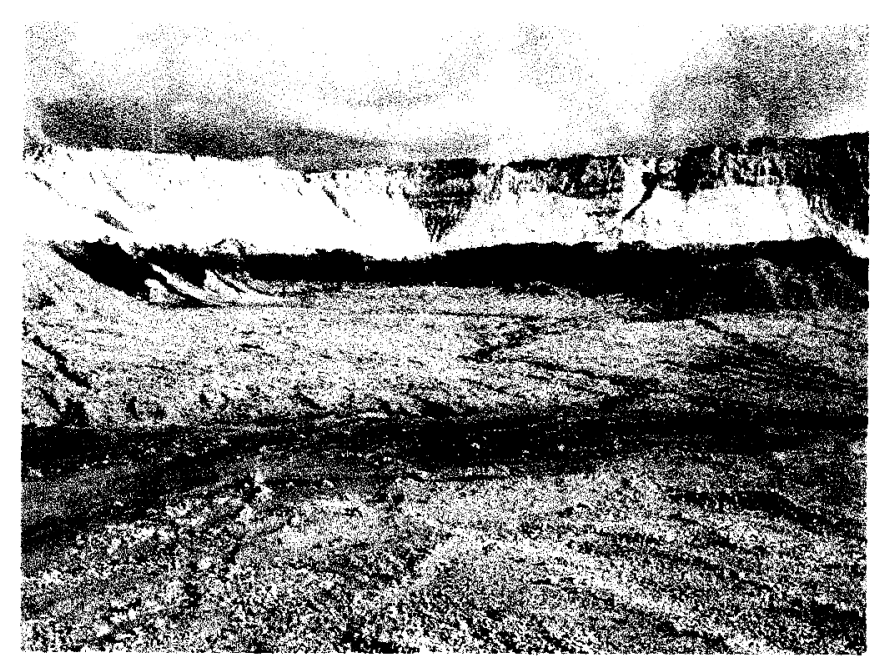

Figure 4: Thick Tertiary sand deposits (white) covering bauxite/laterite deposits at the Linden Mine in Guyana.
A number of bauxite mines and smaller sites were visited to see if any might be suitable as research sites for chemical weathering. It quickly became clear that the greatest obstacle to using any of the laterites in Guyana as field research sites was the extensive cover of the weathering profiles by unconsolidated Tertiary sand deposits. At the Linden mine south of Georgetown, the thickness of the Tertiary sand cover is at least 200 feet (Figure 4). The visit to the mine to examine the laterite deposits also revealed another important fact about the Linden site. Pumping of the mine site was required to lower 
the water table below the level of the bauxite horizon (Figure 5). Bore holes drilled into the bauxite/laterite horizon resulted in artesian flow (Figure 6), indicating that at Linden the weathering regime was no longer active, but was in fact a groundwater aquifer.

Samples of water upwelling from the bore holes showed relatively higher silica contents (a good first order indicator of the extent of weathering) than was found in stream and seepage waters draining surface sites (Table 1), in keeping with the longer residence time expected for waters in the subsurface.

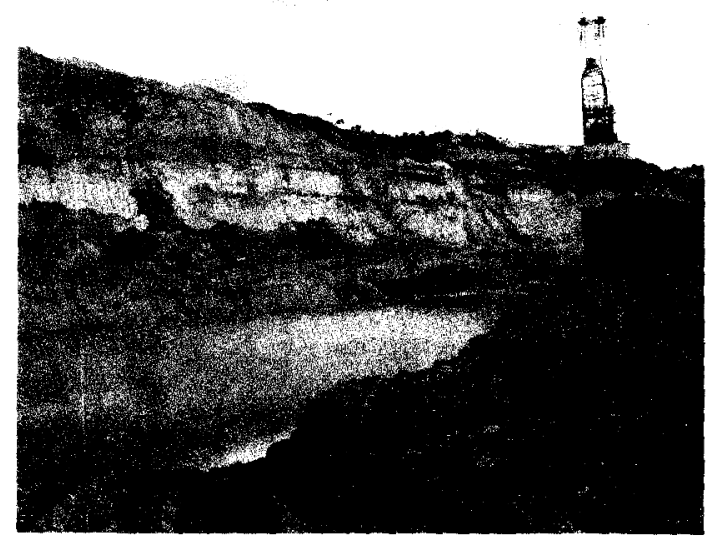

Figure 5: Water accumulating in the Linden Mine due to occurrence of the water table above the laterite horizon.

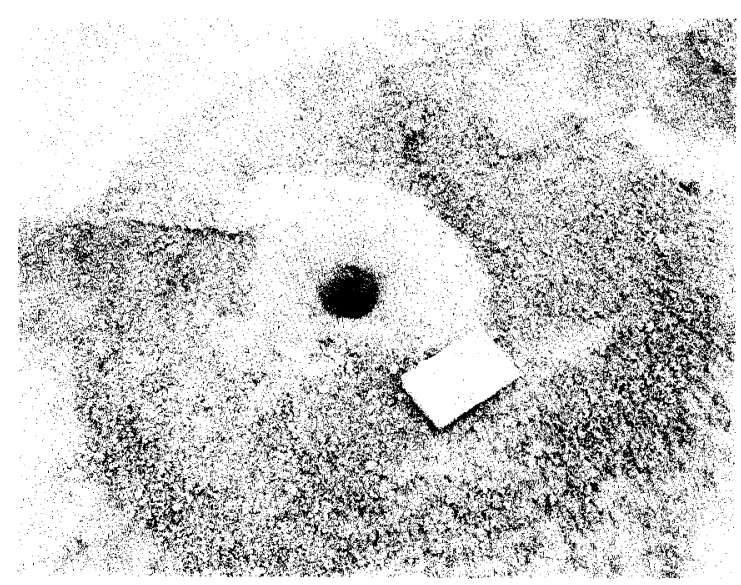

Figure 6: Bore hole drilled into laterite at the Linden Mine showing artesian flow. See Table 1 for water analysis.

The presence of the high water table relative to the laterite horizon and the extensive cover by Tertiary sands precluded the use of Linden or nearby sites as a study area, since it was clear that chemical weathering was not occurring at the present time. Apparently, the laterites at Linden represent the effects of weathering during the earlier Tertiary. The focus of our reconnaissance therefore shifted to laterites that appeared to be located at topographic highs--these sites might provide both direct exposure of laterite and the presence of streams draining the laterite alone, rather than some combination of laterite and Tertiary sand. Perhaps the laterite occurrence which combined these two features best was found in the Block 15 area on the road to Omai in Guyana. Here a small pit at the top of the hill exposed ferruginous bauxite, although thin Tertiary sand deposits occurred nearby. A stream draining the topographic high showed a $\mathrm{pH}$ of 5.85 and a conductivity of $0.12 \mu$ Siemens, indicating very little reaction with rock had occurred prior to collection. A full water analysis is provided in Table 1. Because of the dense vegetation, however, it was impossible to find other streams draining the laterite that might have completed the picture of the chemical weathering flux.

The situation for sampling laterite and streams draining the laterite proved to be even more difficult elsewhere in the region. It became difficult to identify any streams draining the outcropping laterites due to the combination of low relief and dense 
vegetation. One stream was sampled in the Ituni Block 17 which showed a dark coffee color, presumably due to the presence of organic acids in the water (Figure 7). This was corroborated by the $\mathrm{pH}$ value of 4.17 measured in the stream, although based on the local topography, it cannot be stated with certainty that only laterite was sampled here without additional geologic mapping.

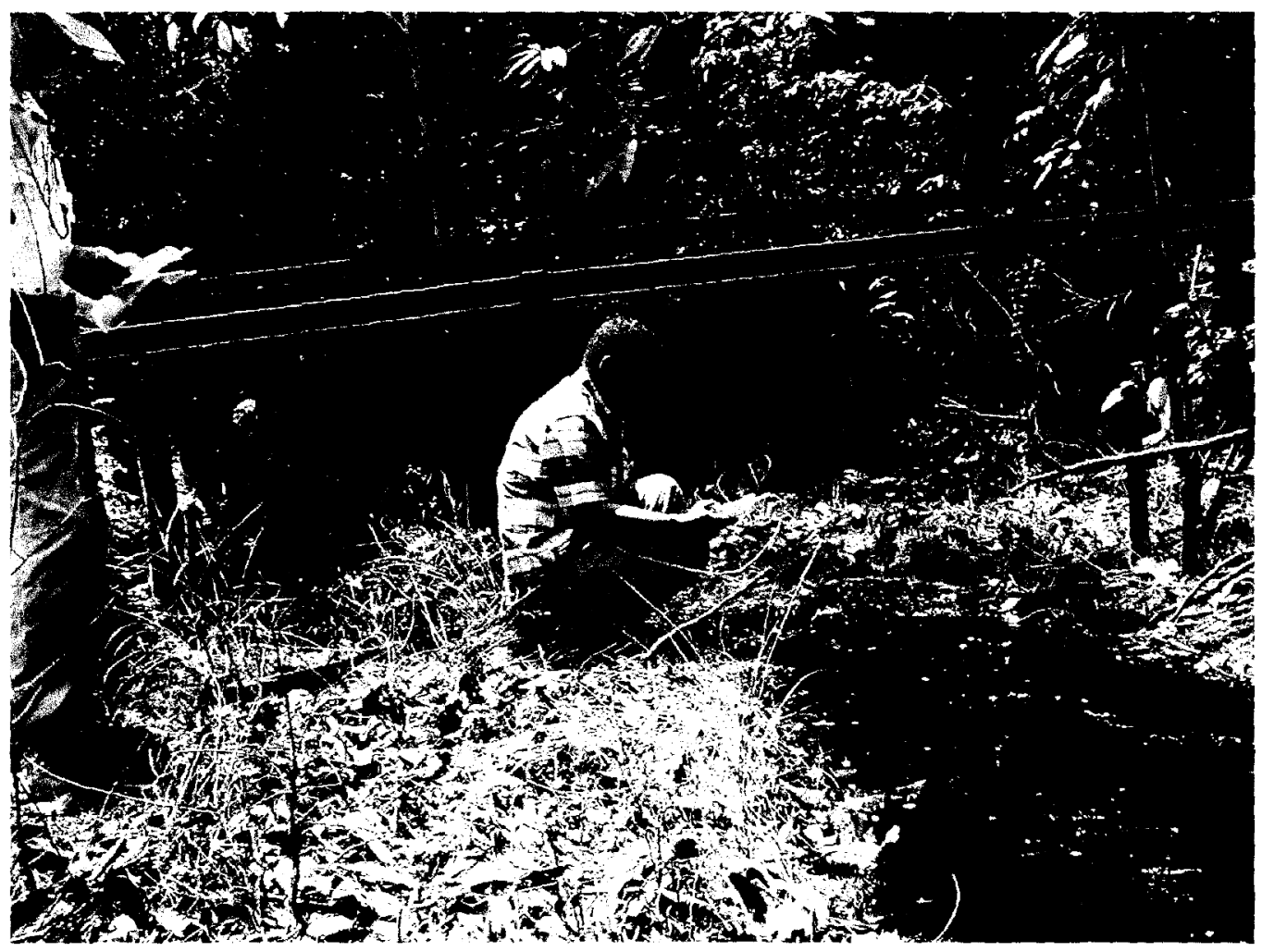

Figure 7: Team members Brian Viani (left) and Armando Ramirez measuring $\mathrm{pH}$ and conductivity in an organic-rich stream in Guyana.

Table 1: Summary of water analyses from laterites in Guyana (concentrations in ppm).

\begin{tabular}{|l|l|c|c|c|c|c|}
\hline \multicolumn{1}{|c|}{ Sample } & \multicolumn{1}{|c|}{ Location } & $\mathbf{p H}$ & $\mathbf{A l}$ & $\mathbf{C a}$ & $\mathbf{M g}$ & $\mathbf{S i}$ \\
\hline Guyana 1 & Artesian flow from bore hole & 5.13 & 0.07 & 0.08 & 0.08 & 4.39 \\
\hline Guyana 2 & Artesian flow from bore hole & N.A. & 0.08 & 0.16 & 0.09 & 4.54 \\
\hline Guyana 3 & Stream, Block 15 (Omai) & 5.85 & 0.14 & 0.81 & 0.60 & 3.27 \\
\hline Guyana 4 & Stream, Block 17 (Ituni) & 4.17 & 0.37 & 0.31 & 0.32 & 0.76 \\
\hline Guyana 5 & Lake, Block 18 (Ituni) & 5.29 & 0.01 & 0.14 & 0.07 & 0.24 \\
\hline Guyana 6 & Pond on kaolinite layer (Ituni) & 5.18 & 0.01 & 0.11 & 0.11 & 0.04 \\
\hline
\end{tabular}

Our final conclusion was that the portion of the Guayana Shield lying within Guyana was not suitable as a research site to study chemical weathering because: 1) the extensive cover by younger sediments provided additional inputs to the dissolved load in streams, thus obscuring the weathering of the basement granitic rock, and 2) exposure is poor due to the lack of topographic relief and the thickness of the jungle vegetation. 


\section{REFERENCES}

Berner, E.K and Berner, R.A., 1996, Global environment: water, air, and geochemical cycles. Prentice-Hall, Upper Saddle River, NJ, 376p.

Kigoshi, K. 1971. Alpha-recoil thorium-234; Dissolution into water and Uranium-234/Uranium238 disequilibrium in nature. Science, 173, 47.

Malmstrom, M.E., G. Destouni, S.A. Banwart, B.H. Stromberg, 2000. Resolving the scaledependence of mineral weathering rates. Environmental Science and Technology, 34(N7): $1375-1378$.

Raymo, M.E. and Ruddiman, W.F., 1992, Tectonic forcing of late Cenozoic climate. Nature, 359, 117-122.

Soler, J.M. and Lasaga, A.C., 2000, The Los Pijiguaos bauxite deposit (Venezuela): A compilation of field data and implications for the bauxitization process. J. of South American Earth Sciences, 13, 47-65.

Steefel, C.I, Rye, R.M, Sak, P.B., and Brantley, S.L (2002) Interpretation of weathering profiles from the Paleo-Proterozoic and present using reactive transport modeling. Abstracts for 2002 Goldschmidt Conference, Davos, Switzerland.

White, A.F., Blum, A.E., Schulz, M.S., Bullen, T.D., Harden, J.W. and Peterson, M.L., 1996. Chemical weathering of a soil chronosequence on granitic alluvium 1.

Reaction rates based on changes in soil mineralogy. Geochim. Cosmochim. Acta, 60, 2533-2550. 